\title{
Digital Currencies of the Central Bank as a Means of Strengthening the Monetization of the Russian Economy
}

\author{
Kiriakova N.I.
}

\author{
Ural State University of Economics, 8 Marta/ Narodnoy Voli, 66/45, Ekaterinburg 620114, Russia \\ Corresponding author. Email: natashkir@yandex.ru
}

\begin{abstract}
This article discusses various approaches to the study of the money market in Russia. The material of discussions about the creation and use of digital currency is analyzed. Statistical data on the dynamics of the main monetary indicators of the Russian economy are presented: M0, M1, M2, the monetary base, the basic coefficients reflecting the degree of monetization of the Russian economy are calculated. The essence of CBDC (central bank digital currency) is defined as obligations of the Central Bank denominated in national currency, having a digital representation and capable of acting as a means of payment, measure and preservation of value. The results of testing the hypothesis about the effect of expanding access of commercial banks to Central Bank liabilities on the monetization ratios of the economy, providing the Russian economy with cash and the prospects for using digital currency (CBDC) are presented.
\end{abstract}

Keywords: digital currency $(C B D C)$, aggregate $M 0, M$, broad monetary base, monetization coefficient

(KME), M1 / GDP, monetary base / GDP, M0 / M2

\section{INTRODUCTION}

Saturation of the economy with liquid financial assets that can perform the functions of money is an important indicator of the development of the country's financial system and economy

Traditional research by Russian scientists in this direction is numerous. They are related to research on the structure of the banking services market and its impact on competition $[1,3,8]$, analysis of trends in the development of the banking system and its stability in a negative economic environment [17]; the impact of the capital adequacy ratio of banks on the credit channel of money transmission in Russia [2], the state and prospects of the Bank Deposit market in Russia $[5,7,8,13,14]$. We also study trends in the development of interbank lending in Russia [4], the rate and volume of Bank reserves as important elements for achieving a balance between the monetary and real sectors of the economy $[10,16]$. The influence of money market multipliers on the economy in various monetary policy regimes is shown $[6,9,12,15]$.

At the same time, the development of new financial and payment technologies, the appearance of private crypto assets that can perform separate functions of money, and the decrease in the share of cash in circulation force the Central Bank to make changes to the state's monetary system.

The issue of creating a digital currency-CBDC(central bank digital currency) - obligations of the Central Bank denominated in the national currency, which have a digital representation and can act as a means of payment, measure and preservation of value. But researchers note that the appearance of another channel that allows you to exchange money held in accounts in commercial banks for Central Bank money (along with or in place of cash), can significantly change the financial system. And it is unknown whether this will weaken or increase the risks of financial stability. In this regard, there was a discussion about the possible advantages and disadvantages of creating a digital currency of the Central Bank.

The main topics of discussion:

- The potential of CBDC is not sufficiently explored and the benefits are difficult to quantify - IMF executives say and emphasize that the digital currency offers "great prospects" in terms of financial integration and also provides confidentiality in payments, but at the same time it can also pose a threat to financial integrity and stability [24.25].

- At the same time, there is the potential to strengthen the transmission mechanism of monetary policy by expanding the range of options, an incentive for the development of competition and innovation in payment systems, alternative financing for creating and distributing money, say Bank of England economists B. Dyson and G. Hodgson [ 21].

- The emergence of CBDC will have a positive impact on GDP due to a reduction in real interest rates, distorting taxes, and monetary transaction costs, according to Bank of England economists Barrdear, J.and Kumhof M. Today the Bank of England already produces digital currency[19].

- Creating a retail CBDC increases the risks to financial stability - and this can create terrible consequences for the financial system, 
economists say the Bank for international settlements C.Barontini, H.Holden, Bech M.L., Faruqui, U., Ougaard, F., Picillo C. [18,20].

- 5.The creation of a system of faster payments has changed the nature of risks of the banking system makes the Bank a competitor to commercial banks, complicates the process of payments economists say the Bank of Denmark Gürtler, K., Nielsen, S.T., Rasmussen, K., Spange, M .[22].

- Money is privacy - says the American economist Kahn, C.M. Replacement of cash with electronic money, the Central Bank will increase the demand for alternative payment means to address privacy concerns[23].

- The appearance of new CBDC money can change the structure of the financial system, but it does not solve the structural problems of the economy, as noted in the analytical note of the Bank of Russia[11].

In General, we can note a cautious attitude to the creation of a digital currency. Most banks and scientists are at the conceptual stage of research on this problem.

\section{RESEARCH METHODOLOGY}

In this work, general scientific and special methods of scientific knowledge were used: logical-theoretical analysis, synthesis, generalization, systemic and integrated approaches, economic-statistical methods - a method of generalizing statistical indicators, a tabular method, a graphing method. The statistical database is represented by the Federal State Statistics Service, Bank of Russia, works of leading domestic and foreign authors, articles published in periodicals. Estimates are made using the analysis of data from the Bank of Russia.

The article presents the results of testing the hypothesis about the effect of expanding access of commercial banks to Central Bank liabilities on the monetization coefficients of the economy, providing the Russian economy with cash and the prospects for using digital currency (CBDC).

This article takes for analysis a 6-year period of development in the Russian economy from 2014 to 2020. This period includes many important events: the introduction of bilateral sanctions, the strengthening of the regulatory role of the Bank of Russia in the economy, changes in monetary indicators, and the global pandemic.

\section{RESEARCH RESULTS}

The ratio M2 / GDP characterizes the degree to which the economy is provided with money, i.e. its liquidity. Relations M1 / GDP and monetary bases / GDP reflect the degree of development of the system of cashless payments in the economy. The monetization coefficient of the economy (CME) reflects the level of functioning of the money market. These tables reflect changes in the level of monetization of the Russian Federation.

Table 1 The main indicators of liquidity in the

\section{Russian Federation}

\begin{tabular}{|c|c|c|c|c|c|c|c|}
\hline Years & 2014 & 2015 & 2016 & 2017 & 2018 & $\begin{array}{l}20 \\
19\end{array}$ & 2020 \\
\hline $\begin{array}{l}\text { M0 } \\
\text { billio } \\
\text { n rub/ }\end{array}$ & $\begin{array}{l}6985 \\
, 6\end{array}$ & $\begin{array}{l}7171 \\
, 5\end{array}$ & $\begin{array}{l}7239, \\
1\end{array}$ & $\begin{array}{l}7714 \\
, 7\end{array}$ & $\begin{array}{l}8446 \\
0\end{array}$ & $\begin{array}{l}93 \\
39, \\
0\end{array}$ & $\begin{array}{l}- \\
9658,4\end{array}$ \\
\hline $\begin{array}{l}\text { M1 } \\
\text { billio } \\
\text { n rub. }\end{array}$ & $\begin{array}{l}1553 \\
6,6\end{array}$ & $\begin{array}{l}1538 \\
8,8\end{array}$ & $\begin{array}{l}16575 \\
, 2\end{array}$ & $\begin{array}{l}1764 \\
2,3\end{array}$ & $\begin{array}{l}19508 \\
, 7\end{array}$ & $\begin{array}{l}21 \\
62 \\
4,1 \\
\end{array}$ & $\begin{array}{l}23861, \\
7\end{array}$ \\
\hline $\begin{array}{l}\text { M2 } \\
\text { billio } \\
\text { n rub. }\end{array}$ & $\begin{array}{l}3140 \\
4,7\end{array}$ & $\begin{array}{l}3211 \\
0,5\end{array}$ & $\begin{array}{l}35809 \\
, 2\end{array}$ & $\begin{array}{l}3841 \\
7,8\end{array}$ & $\begin{array}{l}42440 \\
, 2\end{array}$ & $\begin{array}{l}47 \\
10 \\
9,3 \\
\end{array}$ & 51680 \\
\hline $\begin{array}{l}\text { Mone } \\
\text { tary } \\
\text { base } \\
\text { billio } \\
\text { n rub. }\end{array}$ & $\begin{array}{l}1053 \\
9\end{array}$ & $\begin{array}{l}1133 \\
2\end{array}$ & $\begin{array}{l}11043 \\
, 8\end{array}$ & $\begin{array}{l}1188 \\
2,7\end{array}$ & $\begin{array}{l}14701 \\
, 5\end{array}$ & $\begin{array}{l}16 \\
06 \\
3,4\end{array}$ & $\begin{array}{l}16823, \\
4\end{array}$ \\
\hline $\begin{array}{l}\text { RF } \\
\text { GDP } \\
\text { billio } \\
\text { n rub. }\end{array}$ & $\begin{array}{l}7919 \\
9,7\end{array}$ & $\begin{array}{l}8323 \\
2,6\end{array}$ & $\begin{array}{l}86010 \\
, 2\end{array}$ & $\begin{array}{l}9208 \\
9,3\end{array}$ & $\begin{array}{l}10362 \\
6,6\end{array}$ & $\begin{array}{l}11 \\
00 \\
46, \\
1\end{array}$ & $\begin{array}{l}111806 \\
\text { (good } \\
\text { forecas } \\
\text { t; } \\
110596 \\
.3- \\
\text { with } \\
\text { pande } \\
\text { mics } \\
\text { accoun } \\
t\end{array}$ \\
\hline $\begin{array}{l}\text { CME } \\
(\%)\end{array}$ & $\begin{array}{l}39,6 \\
5 \\
\end{array}$ & $\begin{array}{l}38,5 \\
8\end{array}$ & 41,63 & $\begin{array}{l}1,7 \\
2 \\
\end{array}$ & 40,95 & $\begin{array}{l}42, \\
81\end{array}$ & $\begin{array}{l}46,22 / 4 \\
6,73\end{array}$ \\
\hline $\begin{array}{l}\text { M1/G } \\
\text { DP } \\
(\%) \\
\end{array}$ & $\begin{array}{l}19,6 \\
2\end{array}$ & $\begin{array}{l}18,4 \\
9\end{array}$ & 19,27 & $\begin{array}{l}19,1 \\
6\end{array}$ & 18,83 & $\begin{array}{l}19, \\
65\end{array}$ & $\begin{array}{l}21,34 / 2 \\
1,58\end{array}$ \\
\hline $\begin{array}{l}\text { Mon. } \\
\text { base } \\
\text { /GDP } \\
(\%)\end{array}$ & $\begin{array}{l}13,3 \\
1\end{array}$ & $\begin{array}{l}13,6 \\
2\end{array}$ & 12,84 & $\begin{array}{l}12,9 \\
0\end{array}$ & 14,19 & $\begin{array}{l}14, \\
60\end{array}$ & $\begin{array}{l}15,10 / 1 \\
5,21\end{array}$ \\
\hline $\begin{array}{l}\text { M0/ } \\
\text { M2 } \\
\text { depos } \\
\text { it rate } \\
()(\%)\end{array}$ & $\begin{array}{l}22,2 \\
4\end{array}$ & $\begin{array}{l}22,3 \\
3\end{array}$ & 20,22 & $\begin{array}{l}20,1 \\
0\end{array}$ & 19,90 & $\begin{array}{l}19, \\
83\end{array}$ & 18,69 \\
\hline
\end{tabular}

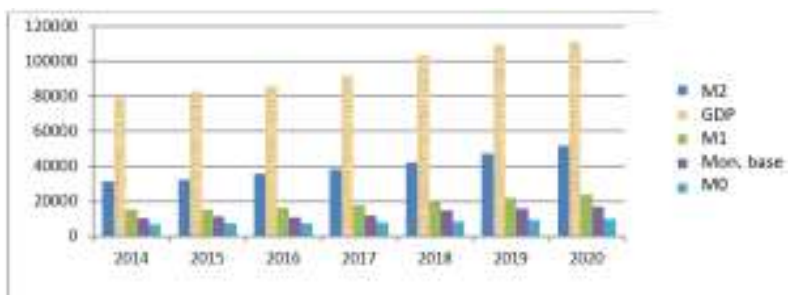

Figure 1 Dynamics of liquidity indicators in the Russian Federation 


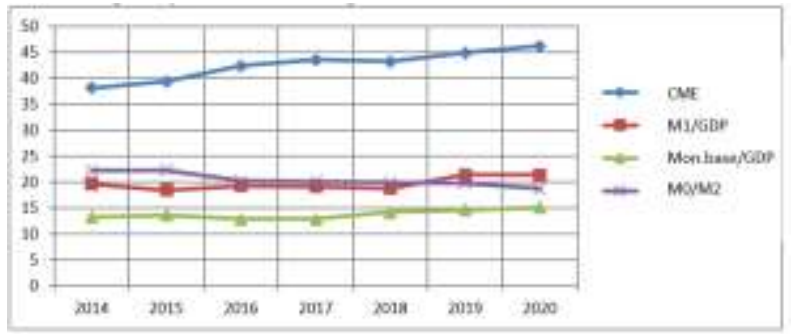

Figure 2 Correlation of liquidity ratios in the Russian economy

Source: compiled by the author according to the Bank of Russia

In modern conditions, the share of cash in circulation is small and is decreasing, which makes non-cash or electronic money the basis of the money supply. But the ratio of cash to non-cash, which reflects the deposit rate and its change, characterizes the level of confidence of the country's population to the banking system [26]. The higher the difference between these indicators, the more developed is the system of cashless payments to the economy. And vice versa, the smaller the difference between these indicators, the less developed the banking system and most of the payments are made in cash.

Despite a slight increase in the monetization coefficient of the Russian economy, it remains quite low and does not exceed $50 \%$. This forces the Bank of Russia to consider ways to expand the access of commercial banks to additional cash. An important role here can be played by the digital currency, which is noted in the analytical note of the Bank of Russia.

\section{DISCUSSION OF RESULTS}

Currently, only commercial banks have access to the balance sheets of central banks; central bank reserves are already held as digital currencies. That is why central banks are so efficient and economical through interbank payments and credit operations. Since private individuals, corporations, and non-bank financial institutions do not enjoy the same access, they must rely on licensed commercial banks to process their transactions. Bank deposits are a form of private money that is used for transactions between non-bank private agents.

The main problem with CBDCs is that they will violate the existing partial reserve system through which commercial banks generate money by issuing more than they hold in liquid deposits. This will increase the imbalance between the money and real sectors of the economy, which will immediately affect the value of money multipliers and will have a negative impact on the economy.

These diagrams illustrate this mechanism.

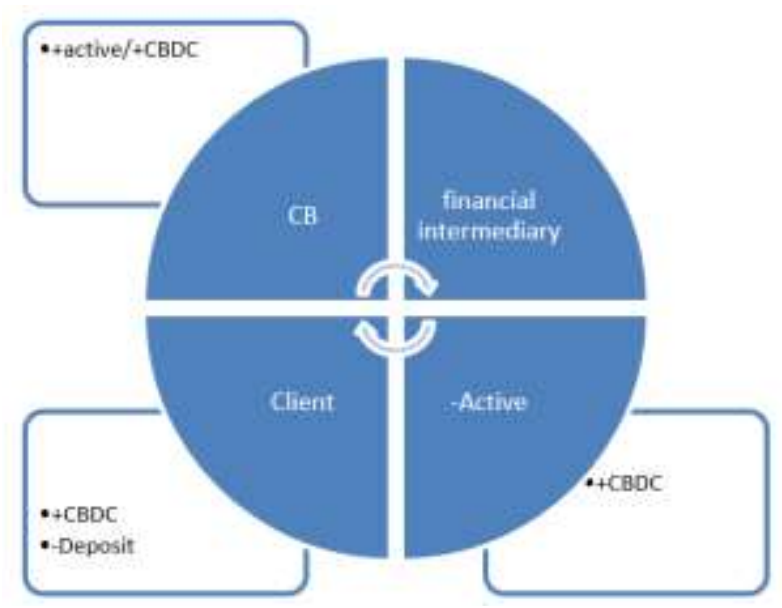

Figure 3 Diagram A creating CBDC and transferring $\mathrm{CBDC}$ to the client ( to the real sector)

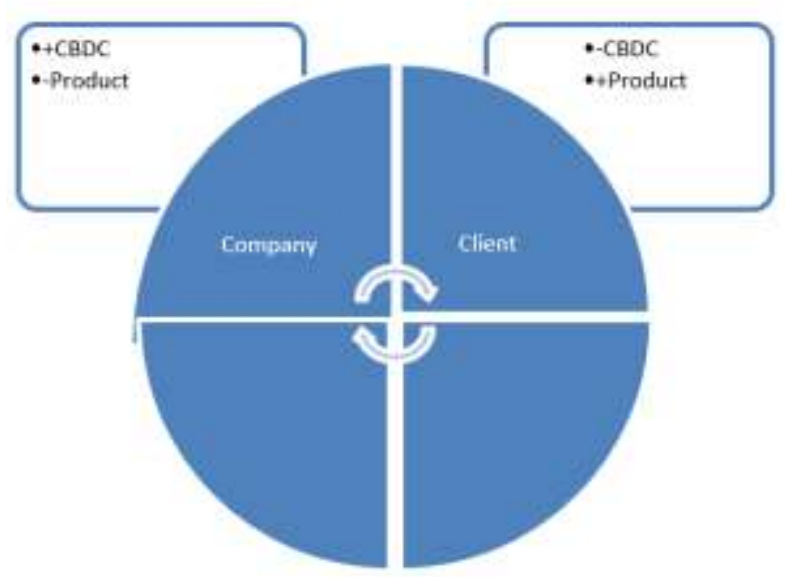

Figure 4 Diagram B.Purchasing a product by a household

If all private Bank deposits are transferred to CBDCs, then commercial banks will become credit intermediaries of funds, borrowing long-term funds to finance long-term loans, such as mortgages.

In this case, the banking system with partial reserves will turn into a narrow banking system, managed mainly by the Central Bank. But if the state is actually the only depositor and supplier of funds to banks, the risk of state interference in their credit decisions will be obvious.

The IMF's decision to develop a public - private partnership between Central banks and private commercial banks is interesting. Individuals could hold regular deposits with financial firms, but transactions would eventually be settled in digital currency between the firms. The advantage of this system is that payments will be immediate, secure, cheap, and potentially semianonymous. In addition, Central banks will maintain a reliable basis for making payments.

One alternative is that central banks should return deposits to private banks that have been transferred to CBDCs. This is a reasonable compromise, but it will not solve the problems of the current banking system with partial 
circulation make the Central Bank think about changes in the monetary system.

Research in the field of digital currencies by Central banks shows that their introduction can have both benefits and significant risks associated with this financial innovation.

The Bank of Russia is now taking a different path creating additional systems and services. For example, systems of rapid payments between citizens that are now being created almost everywhere and allow you to eliminate the restrictions on making such payments by using electronic money that existed in the traditional twolevel banking system.

But the high speed of payments and the flow of funds between banks increases the importance of the problem of liquidity and ensuring competitive offers in the Deposit market for them.

In some cases, these payments may also create financial stability risks. The introduction of such systems will require banks to pay more attention to liquidity management. Therefore, indicators of the degree of monetization of the economy and the dynamics of their changes will continue to be important.

Competitiveness in the global world: economics, science, technology.-2017.-№8 (Part 4) .- C .48-53

[7] Kiriyakova N.I. Deposit multiplier as a reflection of the monetary policy of the state [Text] / N.I. Kiriyakova // Economics and Entrepreneurship.-2017.- No. 10 (Part 2.) (87-2) .- P.183-188

[8] Kiriyakova N.I. Differentiation of interest rates in the money market is an important element in achieving equilibrium between the money and real sectors of the economy [Text] NI Kiriyakova // Economics and Entrepreneurship. No. 8 (part 4.) (85-4), 2017 p.877881.

[9] Kiriyakova NI Money market multipliers in the conditions of neutrality of monetary policy [Text] NI Kiriyakova // Economics and Entrepreneurship. No. 9 (110), 2019 from 587-592.

[10] Kiriyakova N.I. The norm and volume of bank reserves are important elements for achieving a balance between the money and real sectors of the economy [Text] / N.I. Kiriyakova // Financial economy. 2018. No. 7 (Part 6). 686-690.

[11] Kiselev A. Is there a future for digital currencies? CB-Analytical Note of the Bank of Russia, April, 2019 // https: //cbr.ru/content/document/file/71328/analytic_note_190 418_dip.pdf
[6] Kiriyakova N.I. The money multiplier is an important element of the mechanism of establishing equilibrium between the money and the real sectors of the economy [Text] / N.I. Kiriyakova // research journal) .- 2017.- No. 5.- P. 156-164 [Electronic resource] URL: http: //edrj.ru/wp -content / uploads / 2016/08 / EDRJ_05_2017.pdf

reservation. There will still be a risk of credit "bubbles,"
mismatch in maturities fueled by money created by private analysis of the effectiveness of state-owned banks and private banks in Russia: new calculations // Money and [4] Dzansolova B.S. Trends in the development of interbank lending in Russia [Text] / B.S. Dzansolova // (134) .- P.27-32.

[5] Ezangina I.A., Yushkova E.A. The State and Prospects of the Bank Deposit Market in Russia // Economic Research and Development (electronic 
[12] Larina O.I., Sakalo E.Yu. Analysis of the organizational mechanism of monetary regulation in Russia // "State audit. Right. Economy ".2016.№1.p. 84-86.

[13] Nikulina A.N., Abalakin A.A. Deposit policy of commercial banks: tools, problems, prospects [Text] / A.N. Nikulin, A.A. Abalakin // Problems of Economics and Management.-2015.-No. 4 (44) .- P.62-65

[14] Palatova E.Yu. Trends in the development of the Russian deposit market // Modern scientific research and innovation. 2017. No. 3 [Electronic resource]. URL: $\quad$ http://web.snauka.ru/issues/2017/03/80021 (accessed date: 09/29/2017).

[15] Pestova A. Regimes of monetary policy of the Bank of Russia [Text] / A.Pestova // Issues of Economics. 2017.No. 4.S. 38-60.

[16] Sukharev A.N. The required reserves ratio for commercial banks: theory and practice / Finance and credit. 2017.t.23. Issue 41 (761) .p.2456-2458.

[17] Tashtamirov M.R. Trends in the development of the banking system and its stability in the face of negative economic conditions - the Internet journal "Science of Science", volume 9.№1, p.2-3. (Jan-Feb 2017) [Electronic resource] URL: http // naukovedenie.ru

[18] Barontini, C., Holden, H., 2019. Proceeding with Caution - a Survey on Central Bank Digital Currency. Bank of International Settlements Papers.

[19] Barrdear, J., Kumhof, M., 2016. The Macroeconomics of Central Bank Issued Digital Currencies. Bank of England - Working Paper No. 605.

[20] Bech, M.L., Faruqui, U., Ougaard, F., Picillo, C., 2018. Payments are a-changin 'but cash still rules, Bank of International Settlements Quarterly Review.

[21] Dyson, B., Hodgson, G., 2016. Why Central Banks Should Start Issuing Electronic Money. Positive Money.

[22] Gürtler, K., Nielsen, S.T., Rasmussen, K., Spange, M., 2017. Central bank digital currency in Denmark? (Analysis No. 28). Danmarks Nationalbank.

[23] Kahn, C.M., Payment Systems and Privacy. Federal Reserve Bank of St. Louis Review, Fourth Quarter 2018, 337-44.
[24] Khiaonarong, T., Humphrey, D., 2019. Cash Use Across Countries and the Demand for Central Bank Digital Currency. IMF Working Papers.

[25] Mancini-Griffoli, T., Martinez, M. S., Agur, I., Ari, A., Kiff, J., Popescu, A., Rochon, C., 2018. Casting Light on Central Bank Digital Currency. IMF Staff Discussion Notes.

[26] Vorobyov Yu. N., Vorobyova E. I. Investitsionnyy potentsial ekonomiki Rossii: finansovye vozmozhnosti razvitiya [Investment potential of Russia's economy: Opportunities for financing the development]. Izvestiya Uralskogo gosudarstvennogo ekonomicheskogo universiteta $=$ Journal of the Ural State University of Economics, 2019, vol. 20, no. 1, pp. 41-60. DOI: 10.29141/2073-1019-2019-20-1-4 